\title{
1 Potential impacts of transport infrastructure and traffic on bird 2 conservation in Swedish Special Protection Areas
}

Jan Olof Helldin
Affiliation during the study: Calluna AB, Linköpings slott, 58228 Linköping, Sweden

Current affiliation: Swedish Biodiversity Centre, SLU, PO Box 7016, 75007 Uppsala, Sweden

\author{
Email: j-o.helldin@slu.se
}

Tel: +46706075322

\section{Abstract}

The ecological impacts of roads and railways extend into the surrounding landscape, leading to habitat degradation and reduced animal densities within an area that is considerably larger than the actual road or railway corridor. For birds, an extensive meta-analysis has pointed at an average of $20 \%$ density reduction within $1 \mathrm{~km}$ from the infrastructure. I investigated to what extent this density reduction could potentially compromise the habitat quality and conservation value of Swedish Natura 2000 areas designated for the protection of birds (Special Protection Areas; SPAs). A majority (63\%) of Swedish SPAs are at least to some extent found within this $1 \mathrm{~km}$ potential effect zone. The total overlap between SPA and effect zone is 126,000 ha, or $4.2 \%$ of the country's SPA area. There are however large differences among biogeographical regions. In the southern (continental) and coastal regions combined, $25.8 \%$ of the total SPA area fall within the effect zone, representing an estimated $4-7 \%$ reduction in bird abundance within SPAs. The probability of overlap with effect zone is higher for larger SPAs. However, the proportion of overlap is higher for smaller SPAs, and accordingly smaller sites can be assumed to experience a greater impact from transport infrastructure and traffic. The impacts on Natura 2000 sites are particularly concerning as this network of protected areas is a cornerstone to maintain and restore biodiversity within EU. I recommend putting a stronger emphasis in the management of Natura 2000 sites on the potential threats to wildlife conservation caused by transport infrastructure and traffic. Special attention should be paid in sites with a large overlap with the effect zone, and in sites hosting particularly vulnerable taxa or habitats. Infrastructure owners and managers should do their best to minimize and compensate for the negative impacts of roads and railways and related traffic in SPAs and other protected areas. 


\section{Keywords}

Bird conservation, Effect zone, Natura 2000, Railways, Roads, Special Protection Areas, Sweden, Transport infrastructure

\section{Introduction}

Ecological impact of transport infrastructures

Infrastructure development is recognized as one of the significant drivers of the global biodiversity loss, and with increasing traffic and expanding infrastructure networks worldwide the pressure on biodiversity is expected to increase in the nearest decades (EEA 2011, 2012, OECD 2012). The impacts of transport infrastructures on wildlife are well described (reviewed by, e.g., Forman et al. 2003, van der Ree et al. 2015), and include loss of habitat, traffic casualties, creation of physical barriers, disturbance by noise, light and other visual cues, spread of chemicals, dust and alien species, changes in hydrology and microclimate, and accidental spill. Most of these impacts extend into the surrounding landscape, leading to a degradation and fragmentation of habitats, and for some animal species to restricted movements, increased mortality, and avoidance of a zone around the infrastructure (Forman et al. 2003, EEA 2011, van der Ree et al. 2015).

Due to these impacts, the population densities of many animal species are reduced within a distance from larger infrastructures (Rytwinski \& Fahrig 2015). For example, the population densities may be reduced on up to about $1 \mathrm{~km}$ distance for birds (Forman \& Deblinger 2000, Forman et al. 2002, Benítez-López et al. 2010) and anurans (Eigenbrod et al. 2009), and up to $5 \mathrm{~km}$ for mammals (Benítez-López et al. 2010). Not only large infrastructures but also minor and unpaved roads may have a considerable impact on some wildlife species (e.g., van Langevelde \& Jaarsma 2009, Benítez-López et al. 2010, Shanley \& Pyare 2011). Based on an extensive meta-analysis, Benítez-López et al. (2010) showed that the mean bird and mammal abundance in an effect zone around infrastructure is reduced by $20-30 \%$, and with an increasing reduction with proximity to the infrastructure (see Fig. 1).

Accordingly, in regions with dense infrastructure networks, large natural areas may be situated within this effect zone and therefore impoverished in species sensitive to traffic and transport infrastructures. For example, in the United States, the road effect zone covers 15$22 \%$ of the total land area, and more than $60 \%$ of some particularly exposed biomes, such as coastal regions and river basins (Forman 2000, Riiters \& Wickham 2003). In Spain, a country with intermediate road density with European standards, reduced bird densities due to 
64

65

66

67

68

69

transportation infrastructure are expected in $49 \%$ of the country, and reduced mammal densities in as much as $96 \%$ of the country (Torres et al. 2016). Some habitats of particular importance to biodiversity in Europe, such as wetlands, semi-natural grasslands and temperate broad-leaved forest, may be disproportionately affected by roads because of the landscape structure (Helldin et al. 2013, Karlson \& Mörtberg 2015, Torres et al. 2016). Disturbance (noise and visual cues) tend to be stronger and extend further from the road in open habitats as compared to forest (Forman \& Deblinger 2000, Reijnen \& Foppen 2006). There is a growing concern globally about impact of roads and traffic on wildlife populations in protected areas and other biodiversity hotspots (Forman \& Deblinger 2000, Ament et al. 2008, Selva et al. 2011, Laurence \& Balmford 2013, Bager et al. 2015, Gadd 2015, Seshadri \& Ganesh 2015).

Integrity of the Natura 2000 network

The Natura 2000 network of protected areas is a key tool in the maintenance and restoration of biodiversity within the European Union (EU). The network consists of Special Protection Areas (SPAs) designated according to the Birds Directive, and Special Areas of Conservation (SACs) designated according to the Habitats Directive (EEC 1992, 2010). Under these directives, the network is supposed to provide protection for vulnerable wildlife and habitats. One important motivation for designating Natura 2000 sites, particularly in coastal and other lower-elevation areas, is the protection against negative impacts of urbanization and infrastructure development (EEA 2012). There are presently more than 26,400 sites in the Natura 2000 network, accounting for ca $18 \%$ of EUs land territory.

\section{The network is however biased toward highland areas, and lowland areas are} underrepresented (Oldfield et al. 2004, Mariorano et al. 2007). In addition, the average size of the Natura 2000 sites is quite low, and particularly so in lowlands (Maiorano et al. 2007, Gaston et al. 2008, EEA 2012). As smaller sites are more susceptible to pressure from land use and human activities surrounding them, major concerns are expressed about the capacity of existing protected areas to maintain their biodiversity values (Chape et al. 2005, Gaston et al. 2008, Maiorano et al. 2008, Kati et al. 2015).

Though many assessments of the Natura 2000 network’s effectiveness in protecting species have been reported in the last years, a vast majority of these relied on rather static population data, such as species’ geographic distribution, species presence/absence, or habitat suitability (e.g., Araujo et al. 2007, Maiorano et al. 2007, 2015, Sánchez-Fernández et al. 2008, Iojă et al 2010, López-López et al. 2011, Gruber et al. 2012, Albuquerque et al. 2013, D’Amen et al. 
2013, Lison et al. 2013, Rubio-Salcedo et al. 2013, Trochet \& Schmeller 2013), and accordingly were designed to assess ecological representativeness of the network rather than tracking changes in population densities due to environmental impacts. In view of the many negative population trajectories reported for both avian and non-avian species in the EU (EEA 2015), it appears necessary to analyze the ecological functionality of the Natura 2000 network with regard to pressures both within and outside the designated areas, but few studies have taken this course.

Frequency of transport infrastructure within Natura 2000 sites was investigated by Tsiafouli et al. (2013), showing that as a European average, roads are present in 29\% of the sites, with a higher frequency in the countries in the south. A preceding study of Greek Natura 2000 sites, by Votsi et al. (2012), showed that $85 \%$ of sites are bisected by roads. Insufficient functional connectivity of the Natura 2000 network has been reported by Gurrutxaga et al. (2011) and Opermanis et al. (2012), suggesting that dispersal barriers exist between sites, for example in the form of large roads (Gurrutxaga et al. 2011). With regard to disturbance, the European Environmental Agency estimated that almost 20\% of Natura 2000 areas are presently adversely affected by high levels of environmental noise, largely owing to major transport infrastructures (EEA 2016). In an assessment of the impact on Natura 2000 sites of major traffic arteries planned or under construction as part of EU's TEN-T framework, Byron \& Arnold (2008) estimated that 379 SPAs (8\% of sites) and 953 SCIs (4\% of sites) would be adversely affected by these new traffic arteries, with potential effects also on Natura 2000 network coherence.

Aim of the study

Sweden is one of the European countries that are least fragmented by transport infrastructures and built-up areas (EEA 2011), and the physical impact of infrastructure is generally not well acknowledged in Swedish nature conservation. It is not until recently that national status reports for biodiversity have described the threats from infrastructure and traffic on species conservation (Bernes 2011, Naturvårdsverket 2015a), and the current national conservation action plan contains few requirements to infrastructure managers (Naturvårdsverket 2015b). Biodiversity is generally insufficiently described in impact assessments of transportation infrastructure plans and projects (Wärnbeck 2013, Karlson et al. 2014). Few, if any, management plans for protected areas address the full array of potential ecological impacts of transport infrastructures on the areas' conservation status or management (Helldin \& Tytor 2017). This ignorance is not unique for Sweden, but appear to be largely similar in most EU 
130 member states (Tsiafouli et al. 2013, EEA 2015; but see, e.g., Selva et al. 2011, Votsi et al.

131 2012).

132 In order to illustrate and highlight the impacts of infrastructure on protected areas in

133 particular, I estimated the frequency and proportion of Swedish SPAs situated within the

134 potential effect zone for birds around existing larger transport infrastructures (roads and

135 railways), and hence can be expected not to reach their full conservation potential due to

136 infrastructure impacts. I included only SPAs in the estimation, i.e., areas designated

137 specifically for the protection of birds, because the effects of roads and railways on birds are

138 well described in literature and apparently can impact a majority of bird species (Reijnen \&

139 Foppen 2006, Benítez-López et al. 2010, Rytwinski \& Fahrig 2015). I assessed the

140 conservation value of SPAs that is lost due to infrastructure in terms of reduced predicted bird

141 abundance. Because of the large geographic variation over the country in density of the

142 infrastructure network and proportion of area within SPA, I separated the analyses between

143 biogeographical regions. I tentatively explored the association between the infrastructure

144 impact on an individual SPA and its size and dominating habitats. In this paper, I present the

145 results of these analyses and propose improvements for the management of Swedish SPAs.

\section{Methods}

147 A map of the effect zone for birds around the existing larger Swedish transport infrastructure

148 was produced. I assumed a standardized effect distance of $1 \mathrm{~km}$ from the infrastructure,

149 following the result from a meta-analysis presented by Benítez-López et al. (2010). To my

150 knowledge, this is the most comprehensive analysis of infrastructure impacts on bird

151 densities, including 49 bird datasets and 201 bird species. Most studies in the meta-analysis

152 were conducted in biomes that occur in Sweden, i.e., taiga, temperate broadleaf forest or

153 alpine/tundra (39 of the 49 datasets), and on species that occur in Sweden (105 of the 201

154 species), and I therefore judged the results relevant in a Swedish perspective. The results have

155 also previously been applied to assess the impacts of the road network on birds in Sweden

156 (Karlson \& Mörtberg 2015) and Europe (Torres et al. 2016). I consider the assumption of a 1

$157 \mathrm{~km}$ effect distance to be conservative because i) individual studies in the meta-analysis

158 indicated reduced bird populations on larger distances, and ii) impacts on longer distances

159 may not necessarily result in direct population declines, but yet be of ecological significance.

160 Infrastructure data were obtained from Open Street Map (http://openstreetmapdata.com),

161 using only the following road classes: primary road, secondary road, tertiary road, motorway, 
162 trunk road, railway (thus excluding minor roads for which ecological effects are less well

163 known).

164 The effect zone map was overlaid with all Swedish SPAs to calculate the area and proportion

165 of each site situated within the effect zone. Shape of areas and habitat distribution were

166 obtained from European Environment Agency’s Natura 2000 database

167 (http://www.eea.europa.eu/data-and-maps/data/natura-2000-eunis-database). SPAs were

168 separated depending on biome (based on a combination of the Natura 2000 database and

169 Global Biomes data from the CIESIN; http://sedac.ciesin.columbia.edu/data/set/nagdc-

170 population-landscape-climate-estimates-v3/maps?facets=theme:climate) and proximity to

171 coast (data on coastline obtained from Open Street Map; http://openstreetmapdata.com) on the

172 following terms:

173 - continental region: sites with $>50 \%$ of the area within EU continental region,

174 - mixed-forest region: sites with $>50 \%$ of the area within EU boreal region and in CIESIN

175 broadleaf and mixed-forest region,

176 - boreal region: rest of sites within EU boreal region but with no part within EU alpine

177 region, or

178 - alpine region: sites with at least some part of the area within EU alpine region;

179 in combination with

180 - coastal: mainland sites with at least some part within $20 \mathrm{~km}$ from coast of mainland

181 Sweden (including mainland islands Öland and Gotland), or

182 - inland: the rest of mainland sites.

183 The alpine region in Sweden is only inland, i.e., no alpine coastal sites exist. Because only

184 two continental sites are inland, all continental sites were pooled in one region. In addition, an

185 off-coastal region was formed including all sites with no contact with mainland Sweden

186 irrespective of terrestrial biome. Hereby a total of seven biogeographical regions were

187 obtained (see Table 1 and Fig. 2).

188 To assess the bird conservation value of SPAs that is lost due to infrastructure, I assumed an

189 average of $20 \%$ (C.I. $12-33 \%$ ) reduction of bird abundance within the $1 \mathrm{~km}$ effect distance

190 from infrastructure, as indicated by the results presented by Benítez-López et al. (2010; see

191 Fig. 1). GIS analyses were conducted using ArcGIS version 10.2 and QGIS version 2.6.

192 To explore how the degree of impact on an SPA is associated with its size and dominating

193 habitat, two different analyses where performed for each region. For the probability of

194 overlap with effect zone (response variable either 0 or 1 ), a generalized linear model with a 
logit link function (logistic regression) was used, and for the proportion of overlap with the effect zone (i.e., a response variable between 0 and 1), a beta-regression model (Ferrari \&

197 Cribari-Neto 2004) was used. In both types of models explanatory variables were 1) SPA size,

198 2) proportion forest habitat, 3) proportion wetlands, and 4) proportion agricultural land and

199 grasslands. SPA size was log-transformed to improve normality and all variables were

200 standardized to make parameter estimates comparable. Model selection was based on AIC

201 and the final models were the ones with a combination of explanatory variables resulting in

202 the lowest AIC. Statistical analyses were conducted using program R version 3.4.2.

\section{Results}

204 The overlay of SPAs and effect zone of larger transport infrastructures showed that 339 of

205 Sweden's 538 SPAs (63\%) have at least some part, and 123 (23\%) have most of their area,

206 within the effect zone (Table 1). In terms of area, a total of ca 126,000 ha, or $4.2 \%$ of the total

207 SPA area in the country, lies within the effect zone.

208 National level figures on impacted area however gives a crude picture, as the results pointed

209 at large differences among the biogeographical regions (Table 1). Alpine and marine areas

210 have a number of large SPAs and hold most of Sweden's total SPA area, but have sparse

211 networks of large (terrestrial) transport infrastructures, and accordingly they reduce the

212 national average. Continental, mixed-forest coastal and boreal coastal regions, however, are

213 comparably more impacted; in these three regions combined a total of 46,046 ha, or 25.8\% of

214 the total SPA area, fall within the effect zone. In terms of bird conservation value, present

215 infrastructure impacts are estimated to cause a 4-7\% reduction in bird abundance in SPAs in

216 the three most impacted regions (continental, mixed-forest coastal and boreal coastal), and an

217 average of 1\% reduction when all SPAs in the country are taken in consideration (Table 1).

218 The overlap models with the lowest AIC included SPA size or habitat composition in all

219 regions except the continental (Table 2). As the most emergent pattern, larger SPAs appear to

220 have a higher probability of overlap with effect zone (in three regions) but a lower proportion

221 of overlap with effect zone (in all regions except continental). Another pattern, however less

222 emergent, is that the overlap with effect zone is larger in SPAs with more agricultural land

223 and grasslands (in four regions), and smaller in SPAs with more forest habitat (in two

224 regions). 


\section{Discussion}

226 The results indicate that a significant proportion of Swedish SPAs, both in terms of area and

227 number of sites, lies within a potential effect zone for birds around present larger transport

228 infrastructures and therefore can be assumed not to reach their full potential as bird habitat.

229 The reduction due to transport infrastructure impacts may not be dramatic when seen on the

230 country as a whole, with only around 4\% of the total SPA area affected, corresponding to a ca

231 1\% reduction in predicted bird abundance within SPAs. However, for more urbanized parts of

232 the country, with a denser infrastructure network, the predicted impact and reduction is nearly

233 an order of magnitude larger and may well be one of the main factors determining bird

234 abundance in protected areas. This is the case in the southern (continental) and coastal regions

235 of the country, where the urbanization and landscape fragmentation is in level with that of

236 most western and central European countries (EEA 2011).

237 At the level of individual SPAs, smaller sites tend to have a higher proportion of overlap with

238 the effect zone and accordingly can be assumed to experience a greater impact than larger

239 sites. This pattern emerge in all biogeographical regions, except the continental where most

240 SPAs are small and indeed impacted to a large degree. In effect, the larger impact on smaller

241 sites amplifies the bias against area protection in the lowlands, i.e., the southern and coastal

242 regions. This is in line with general concerns previously expressed about the small size of

243 many protected areas in Europe and about the impacts from transport infrastructure, traffic

244 and other urban development in the landscape surrounding them (Shafer 1995, Gaston et al.

245 2008, Maiorano et al. 2008, Kati et al. 2015). However, as indicated by Helldin \& Tytor

246 (2017), these concerns are not well expressed in the management plans for Swedish SPAs,

247 and appear particularly underestimated in the regions where the impacts are the largest.

248 The function of predicted bird abundance and distance to infrastructure described by Benítez-

249 López et al. (2010) have previously been applied twice to assess the ecological impact of an

250 infrastructure network on a larger geographical level. Karlson \& Mörtberg (2015) presented

251 an assessment of the impacts of roads on habitats of high diversity value in Sweden

252 (irrespective of their protection status), concluding that natural grasslands and southern

253 broadleaved forest are likely to be particularly impacted; on national level, 13-19\% and 16-

$25424 \%$ of the total areas of these habitats are found within predicted effect zone for birds. Torres

255 et al. (2016) estimated a 19.0\% (CI = 9.6-25.6\%) reduction in national bird numbers due to

256 transport infrastructure for Spain, with all land in view and not only protected areas. They too

257 concluded that some habitats (most notably farmland and maritime wetlands) might be 
disproportionally affected by transport infrastructure. In relation to these previous assessments, the present study is unique in that it points out the impacts specifically on protected areas, i.e., areas where nature conservation should be a top priority.

261 The assessment was aimed to give a general picture, and was therefore simplified in several

262 respects. A fixed-width effect zone is less realistic, as the actual effect depend on the local

263 context, such as the habitat distribution, topography, species and ecological processes

264 involved (Forman \& Dubliner 2000, Ritter’s \& Wickham 2003, Bilging \& Duping-Giroux

265 2006) or the road characteristics (e.g., Reined \& Fop pen 2006, Rytwinski \& Fahrig 2015).

266 Also the stronger reduction in bird densities near the infrastructure within the effect zone (Fig.

267 1) provides an opportunity to assess the decline in bird abundance within the effect zone in

268 individual sites in greater detail than here conducted (e.g., Torres et al. 2016).

269 Furthermore, the analysis of impacts of different habitats within SPAs was rather coarse, 270 since the Natura 2000 database does not provide habitat maps. Therefore, I could not explore

271 to what degree EU priority habitats (habitat types of community interest; EEC 1992) are

272 distributed disproportionally within the effect zone.

\section{Implications for management of protected areas}

274 The present study underlines the concern about the impact of transport infrastructures on

275 wildlife in protected areas in general (Forman \& Deblinger 2000, Ament et al. 2008, Selva et 276 al. 2011, Tsiafouli et al. 2013), and in the smaller areas in particular (Shafer 1995, Maiorano

277 et al. 2008). Following article 4 of the Birds Directive, EU Member States must take

278 appropriate steps to avoid habitat deterioration and significant species disturbance within 279 SPAs (EEC 2010). Accordingly, a stronger emphasis on keeping natural areas free from the 280 impacts of heavy traffic and new roads and railways has been proposed for conservation and 281 transport planning (Selva et al. 2011, 2015, Laurance \& Balmford 2013, IENE 2015).

282 Management plans for Natura 2000 sites should better acknowledge the threats to wildlife 283 conservation caused by both present transport infrastructure and new development projects in 284 and near sites (Cortina \& Boggia 2014, Helldin \& Tytor 2017). Assessments of the 285 effectiveness of individual Natura 2000 sites in maintaining biodiversity should include 286 monitoring of population density and demography of species of special conservation concern

287 (Gaston et al. 2006). Managers of Natura 2000 sites have the opportunity to conduct more 288 detailed assessments of predicted impacts from transport infrastructure based on habitat maps, 289 species occurrences, and local road characteristics, to serve as a basis for priorities in 
conservation planning and action. Special attention to road effects should thus be paid in protected areas with a large overlap with the effect zone, in areas hosting particularly vulnerable taxa, and in areas with pronounced impacts on EU priority habitats.

Conservation authorities should secure that infrastructure owners and managers do their best to minimize the negative impact of nearby roads and railways and related traffic. Technical mitigation of impacts of transport infrastructure on birds could include preventing birdvehicle collision (e.g., with flight diverters), planning the timing of infrastructure maintenance and construction work to avoid particularly sensitive periods, providing crossing structures (safe over-/underpasses), and reducing noise and visual impacts through walls, berms or adapted paving. Traffic calming, speed reduction or road closing (permanent or temporary) would also provide reductions in road mortality, disturbance and barrier effects. Finally, compensatory measures such as habitat improvement or additional area protection could reinforce remnant populations and restore vital ecological processes.

\section{Acknowledgements}

I am grateful to Vadym Sokol for assisting in GIS data retrieval and GIS analyses, and to Victor Johansson for assisting in the statistical analyses. I am also grateful to Lars Nilsson for providing helpful comments on earlier drafts of this paper. I thank Ana Benítez-López and coworkers for kind permission to reproduce their published figure. The study was financed by the Swedish Transport Administration as part of the research program TRIEKOL (triekol.se).

\section{References}

Albuquerque FS, Assunção-Albuquerque MJT, Cayuela L, Zamora R, Benito BM (2013) European Bird distribution is "well” represented by Special Protected Areas: Mission accomplished? Biological Conservation 159: 45-50.

Ament R, Clevenger AP, Yu O, Hardy A (2008) An Assessment of Road Impacts on Wildlife Populations in U.S. National Parks. Environmental Management 42: 480-496.

Araújo MB, Lobo JM, Moreno JC (2007) The effectiveness of Iberian protected areas in conserving terrestrial biodiversity. Conservation Biology 21: 1423-1432.

Bager A, Borghi CE, Secco H (2015) The influence of economics, politics and environment on road ecology in South America. Pp 407-413 in: van der Ree R, Smith DJ, Grilo C (Eds.). Handbook of Road Ecology. John Wiley \& Sons Ltd, UK.

Benítez-López A, Alkemade R, Verweij PA (2010) The impacts of roads and other infrastructure on mammal and bird populations: A meta-analysis. Biological Conservation 143: 1307-1316.

Bernes C (2011) Biodiversity in Sweden. Monitor 22, Swedish Environmental Protection Agency, Stockholm. 
Biglin K, Dupigny-Giroux L-A (2006) Mapping the road-effect zone to assess impacts of proposed road segments. Journal of Conservation Planning 2: 1-16.

Byron H, Arnold L (2008) TEN-T and Natura 2000: the way forward. An assessment of the potential impact of the TEN-T Priority Projects on Natura 2000. Report from BirdLife International. http://www.birdlife.org/eu/pdfs/TEN_T_report2008_final.pdf

Chape S, Harrison J, Spalding M, Lysenko I (2005) Measuring the extent and effectiveness of protected areas as an indicator for meeting global biodiversity targets. Phil. Trans. R. Soc. B 360: 443-455.

Cortina C, Boggia A (2014) Development of policies for Natura 2000 sites: A multi-criteria approach to support decision makers. Journal of Environmental Management 141: 138145.

D'Amen M, Bombi P, Campanaro A, Zapponi L, Bologna MA, Mason F (2013) Protected areas and insect conservation: questioning the effectiveness of Natura 2000 network for saproxylic beetles in Italy. Animal Conservation 16(4): 370-378.

EEA (2011) Landscape fragmentation in Europe; Joint EEA-FOEN report. EEA report No 2/2011. European Environment Agency, Copenhagen.

EEA (2012) Protected areas in Europe - an overview. EEA report No 5/2012. European Environment Agency, Copenhagen.

EEA (2015) State of nature in the EU; Results from reporting under the nature directives 2007-2012. EEA report No 2/2015. European Environment Agency, Copenhagen.

EEA (2016) Quiet areas in Europe; The environment unaffected by noise pollution. EEA report No 14/2016. European Environment Agency, Copenhagen.

EEC (1992) Council Directive 92/43/EEC of 21 May 1992 on the conservation of natural habitats and of wild fauna and flora. Official Journal of the European Communities No L 206/7-50.

EEC (2010) Directive 2009/147/EC of the European Parliament and of the Council of 30 November 2009 on the conservation of wild birds. Official Journal of the European Union No L 20/7-25.

Eigenbrod F, Hecnar SJ, Fahrig L (2009) Quantifying the Road-Effect Zone: Threshold Effects of a Motorway on Anuran Populations in Ontario, Canada. Ecology and Society 14(1): 24.

Ferrari S, Cribari-Neto F (2004) Beta Regression for Modelling Rates and Proportions. Journal of Applied Statistics 31(7): 799-815.

360 Forman RTT, Deblinger RD (2000) The ecological road-effect zone of a Massachusetts

Forman RTT, Reineking B, Hersperger AM (2002) Road traffic and nearby grassland bird

Forman RTT (2000) Estimate of the area affected ecologically by the road system in the United States. Conservation Biology 14(1): 31-35. (U.S.A.) suburban highway. Conservation Biology 14: 36-46.

patterns in a suburbanizing landscape. Environmental Management 29(6): 782-800.

Forman RTT, Sperling D, Bissonette JA, Clevenger AP, Cutshall CD, Dale VH, Fahrig L, France R, Goldman CR, Haenue K, Jones JA, Swanson FJ, Turrentine T, Winter TC (2003) Road ecology - Science and solutions. Island Press (Washington, USA). 
Gadd ME (2015) Expected effects of a road across the Serengeti. Pg 455-464 in: van der Ree R, Smith DJ, Grilo C (Eds). Handbook of Road Ecology. John Wiley \& Sons Ltd, UK.

Gaston KJ, Jackson SF, Nagy A, Cantú-Salazar L, Johnson M (2008) Protected Areas in Europe; Principle and Practice. Ann. N.Y. Acad. Sci. 1134: 97-119.

Gruber B, Evans D, Henle K, Bauch B, Schmeller D, Dziock F, Henry PY, Lengyel S, Margules C, Dormann C (2012) “Mind the gap!” - How well does Natura 2000 cover species of European interest? Nature Conservation 3: 45-62.

Gurrutxaga M, Rubio L, Saurac S (2011) Key connectors in protected forest area networks and the impact of highways: A transnational case study from the Cantabrian Range to the Western Alps (SW Europe). Landscape and Urban Planning 101: 310-320.

Helldin J-O, Tytor S (2017) Hur uppmärksammas ekologiska effekter av vägar och järnvägar inom naturvården? - innehållsanalys av bevarandeplaner för Natura 2000-områden. Report from Calluna AB. http://www.calluna.se/userfiles/files/5_Innehållsanalys_SPA_bevarandeplaner_2017(1).p df (In Swedish)

Helldin J-O, Collinder P, Bengtsson D, Karlberg Å, Askling J (2013) Assessment of traffic noise impact in important bird sites in Sweden - a practical method for the regional scale. Oecologia Australis 17(1): 70-84.

Iojă CI, Pâtroescu M, Rozylowicz L, Popescu VD, Verghelet M, Zotta MI, Felciuc M (2010) The efficacy of Romania's protected areas network in conserving biodiversity. Biological Conservation 143: 2468-2476.

Karlson M, Mörtberg U (2015) A spatial ecological assessment of fragmentation and disturbance effects of the Swedish road network. Landscape and Urban Planning 134: $53-65$.

Karlson M, Mörtberg U, Balfors B (2014) Road ecology in environmental impact assessment. Environmental Impact Assessment Review 48: 10-19.

Kati V, Hovardas T, Dieterich M, Ibisch PL, Mihok B, Selva N (2015) The challenge of implementing the European network of protected areas Natura 2000. Conservation Biology 29(1): 260-270.

Laurance WF, Balmford A (2013) A global map for road building. Nature 495: 308-309.

Lison F, Palazon JA, Calvo JF (2013) Effectiveness of the Natura 2000 Network for the conservation of cave-dwelling bats in a Mediterranean region. Animal Conservation 16(5): 528-537.

López-López P, Maiorano L, Falcucci A, Barba E, Boitani L (2011) Hotspots of species richness, threat and endemism for terrestrial vertebrates in SW Europe. Acta Oecologica 37(5): 399-412.

Maiorano L, Falcucci A, Garton EO, Boitani L (2007) Contribution of the Natura 2000 Network to Biodiversity Conservation in Italy. Conservation Biology 21(6): 1433-1444.

Maiorano L, Falcucci A, Boitani L (2008) Size-dependent resistance of protected areas to land-use change. Proc. R. Soc. B 275: 1297-1304.

Naturvårdsverket (2015a) Målövergripande analys av miljömålen; Underlag till fördjupad utvärdering av miljömålen 2015. Swedish Environmental Protection Agency, Report No 6692. (In Swedish) 
Naturvårdsverket (2015b) Styr med sikte på miljömålen - Naturvårdsverkets fördjupade utvärdering av miljömålen 2015. Swedish Environmental Protection Agency, Report No 6666. (In Swedish)

OECD (2012) OECD Environmental Outlook to 2050; The Consequences of Inaction. OECD Publishing, Paris. http://dx.doi.org/10.1787/9789264122246-en

Oldfield TEE, Smith RJ, Harrop SR, Leader-Williams N (2004) A gap analysis of terrestrial protected areas in England and its implications for conservation policy. Biological Conservation 120: 307-313.

Opermanis O, MacSharry B, Aunins A, Sipkova Z (2012) Connectedness and connectivity of the Natura 2000 network of protected areas across country borders in the European Union. Biological Conservation 153: 227-238.

Reijnen R, Foppen R (2006) Impact of road traffic on breeding bird populations. Pp. 255-274 in: Davenport, Davenport J (Eds) The Ecology of Transportation: Managing Mobility for the Environment. Springer, Dordrecht, the Netherlands.

Riitters KH, Wickham JD (2003) How far to the nearest road? Front. Ecol. Environ. 1(3): 125-129.

Rubio-Salcedo M, Martínez I, Carreño F, Escudero A (2013) Poor Effectiveness of the Natura 2000 Network Protecting Mediterranean Lichen Species. Journal for Nature Conservation 21(1): 1-9.

Rytwinski T, Fahrig L (2015) The Impacts of Roads and Traffic on Terrestrial Animal Populations. Pp 237-246 in: van der Ree R, Smith DJ, Grilo C (Eds.). Handbook of Road Ecology. John Wiley \& Sons Ltd, UK.

Sánchez-Fernández D, Bilton DT, Abellán P, Ribera I, Velasco J, Millán A (2008) Are the endemic water beetles of the Iberian Peninsula and the Balearic Islands effectively protected? Biological Conservation 141(6): 1612-1627.

Selva N, Kreft S, Kati V, Schluck M, Jonsson B-G, Mihok B, Okarma H, Ibisch PL (2011) Roadless and Low-Traffic Areas as Conservation Targets in Europe. Environmental Management 48: 865-877.

Seshradi KS, Ganesh T (2015) Road ecology in south India: issues and mitigation opportunities. Pg 425-429 in: van der Ree R, Smith DJ, Grilo C (Eds). Handbook of Road Ecology. John Wiley \& Sons Ltd, UK.

Shanley CS, Pyare S (2011) Evaluating the road-effect zone on wildlife distribution in a rural landscape. Ecosphere 2(2): 16.

Shafer CL (1995) Values and Shortcomings of Small Reserves: Dealing with the smallest habitat fragments when some of them are all that is left. BioScience 45(2): 80-88.

Torres A, Jaeger JAG, Alonsoa JC (2016) Assessing large-scale wildlife responses to human infrastructure development. PNAS 113(30): 8472-8477. https://doi.org/10.1073/pnas.1522488113

Trochet A, Schmeller DS (2013) Effectiveness of the Natura 2000 network to cover threatened species. Nature Conservation 4: 35-53.

Tsiafouli MA, Apostolopoulou E, Mazaris AD, Kallimanis AS, Drakou EG, Pantis JD (2013) Human Activities in Natura 2000 Sites: A Highly Diversified Conservation Network. Environmental Management 51: 1025-1033. 
van der Ree R, Smith DJ, Grilo C (2015). Handbook of Road Ecology. John Wiley \& Sons Ltd, UK.

van Langevelde F, Jaarsma CF (2009) Modeling the effect of traffic calming on local animal population persistence. Ecology and Society 14(2): 39.

Votsi N-E, Mazaris AD, Kallimanis AS, Zomeni MS, Vogiatzakis IN, Sgardelis SP, Pantis JD (2012) Road effects on habitat richness of the Greek Natura 2000 network. Nature Conservation 1: 53-71.

Wärnbäck A (2013). Beaktande av biologisk mångfald och ekosystemtjänster i miljökonsekvensbeskrivningar och miljöbedömningar. Annex 5 to SOU 2013:68, Synliggöra värdet av ekosystemtjänster - Åtgärder för välfärd genom biologisk mångfald och ekosystemtjänster. liggora-vardet-av-ekosystemtjanster-sou-201368 (In Swedish) 


\section{Tables}

467 Table 1. Number, area and proportion of Swedish SPAs within an assumed effect zone of 1 $468 \mathrm{~km}$ from larger transport infrastructure, and predicted total reduction in bird abundance (with 469 95\% confidence interval) due to the effects. Results are given for the entire country and 470 separated by biogeographical region.

\begin{tabular}{|lccccccc|}
\hline Region & $\begin{array}{c}\text { Total } \\
\text { no. of } \\
\text { SPAs }\end{array}$ & $\begin{array}{c}\text { Total area } \\
\text { of SPA } \\
\text { (ha) }\end{array}$ & \multicolumn{2}{c}{$\begin{array}{c}\text { No. of SPAs } \\
\text { affected to }\end{array}$} & $\begin{array}{c}\text { Total area } \\
\text { of SPA in } \\
\text { effect zone } \\
\text { (ha) }\end{array}$ & $\begin{array}{c}\text { Proportion } \\
\text { of total SPA } \\
\text { in effect } \\
\text { zone (\%) }\end{array}$ & $\begin{array}{c}\text { Reduction in } \\
\text { bird } \\
\text { abundance } \\
\text { (\% with C.I.) }\end{array}$ \\
\hline Continental & 41 & 53,331 & 41 & 18 & 19,202 & 36.0 & $7.2(4.3-11.9)$ \\
\hline Mixed-forest coastal & 94 & 103,064 & 71 & 24 & 20,865 & 20.2 & $4.0(2.4-6.7)$ \\
\hline Mixed-forest inland & 161 & 258,804 & 119 & 43 & 34,622 & 13.4 & $2.7(1.6-4.4)$ \\
\hline Boreal coastal & 22 & 21,712 & 15 & 8 & 5,968 & 27.5 & $5.5(3.3-9.1)$ \\
\hline Boreal inland & 130 & 162,924 & 63 & 30 & 13,122 & 8.1 & $1.6(1.0-2.7)$ \\
\hline Alpine (only inland) & 26 & $1,984,005$ & 16 & 0 & 28,242 & 1.4 & $0.3(0.2-0.5)$ \\
\hline Off-coastal & 64 & 415,308 & 14 & 0 & 3,913 & 1.0 & $0.2(0.1-0.3)$ \\
\hline & & & & & & & \\
\hline All Sweden & 538 & $2,999,149$ & 339 & 123 & 125,946 & 4.2 & $0.8(0.5-1.4)$ \\
\hline
\end{tabular}


Table 2. Variables associated with effect zone overlap with Swedish SPAs divided by biogeographical region. Values given are mean estimates of coefficients of logistic regressions and beta-regressions with standard errors (SE) and probabilities (P). Values are only given for variables that were included in the final model.

\begin{tabular}{|c|c|c|c|c|c|c|c|c|}
\hline \multirow[b]{2}{*}{ Region } & \multicolumn{2}{|c|}{ Log(size) } & \multicolumn{2}{|c|}{ Forested area } & \multicolumn{2}{|c|}{ Wetland } & \multicolumn{2}{|c|}{ Agri \& grassland } \\
\hline & $\begin{array}{c}\text { Estimate } \\
\text { (SE) }\end{array}$ & $P$ & $\begin{array}{l}\text { Estimate } \\
\text { (SE) }\end{array}$ & $P$ & $\begin{array}{l}\text { Estimate } \\
\text { (SE) }\end{array}$ & $P$ & $\begin{array}{l}\text { Estimate } \\
\text { (SE) }\end{array}$ & $P$ \\
\hline \multicolumn{9}{|c|}{ Logistic regression (probability of overlap) } \\
\hline Continental $\dagger$ & - & - & - & - & - & - & - & - \\
\hline Mixed-forest coastal & $0.45(0.27)$ & 0.094 & & & & & & \\
\hline Mixed-forest inland & & & & & $0.49(0.21)$ & 0.019 & $0.91(0.38)$ & 0.016 \\
\hline Boreal coastal & & & $-1.06(0.57)$ & 0.065 & & & & \\
\hline Boreal inland & & & $-2.61(0.75)$ & $<0.001$ & $-2.06(0.70)$ & $<0.001$ & & \\
\hline Alpine (only inland) & $1.31(0.64)$ & 0.039 & & & & & & \\
\hline Off-coastal & $1.07(0.40)$ & 0.008 & & & & & & \\
\hline \multicolumn{9}{|c|}{ Beta-regression (proportion of overlap) } \\
\hline \multicolumn{9}{|l|}{ Continental $\ddagger$} \\
\hline Mixed-forest coastal & $-0.56(0.15)$ & $<0.001$ & & & & & $0.44(0.15)$ & 0.002 \\
\hline Mixed-forest inland & $-0.64(0.12)$ & $<0.001$ & & & & & $0.47(0.11)$ & $<0.001$ \\
\hline Boreal coastal & $-0.85(0.34)$ & 0.013 & & & & & & \\
\hline Boreal inland & $-0.56(0.16)$ & $<0.001$ & $-0.48(0.16)$ & 0.004 & & & $0.43(0.16)$ & 0.009 \\
\hline Alpine (only inland) & $-0.78(0.11)$ & $<0.001$ & & & $-0.38(0.17)$ & 0.022 & & \\
\hline Off-coastal & $-1.09(0.24)$ & $<0.001$ & & & & & $0.40(0.19)$ & 0.036 \\
\hline
\end{tabular}

$\dagger$ Could not be analyzed as all sites had value 1, i.e., overlap to some degree with the effect zone.

$\ddagger$ No variable contributed to the final model; i.e., the model including only the intercept had the lowest AIC. 


\section{Figures}

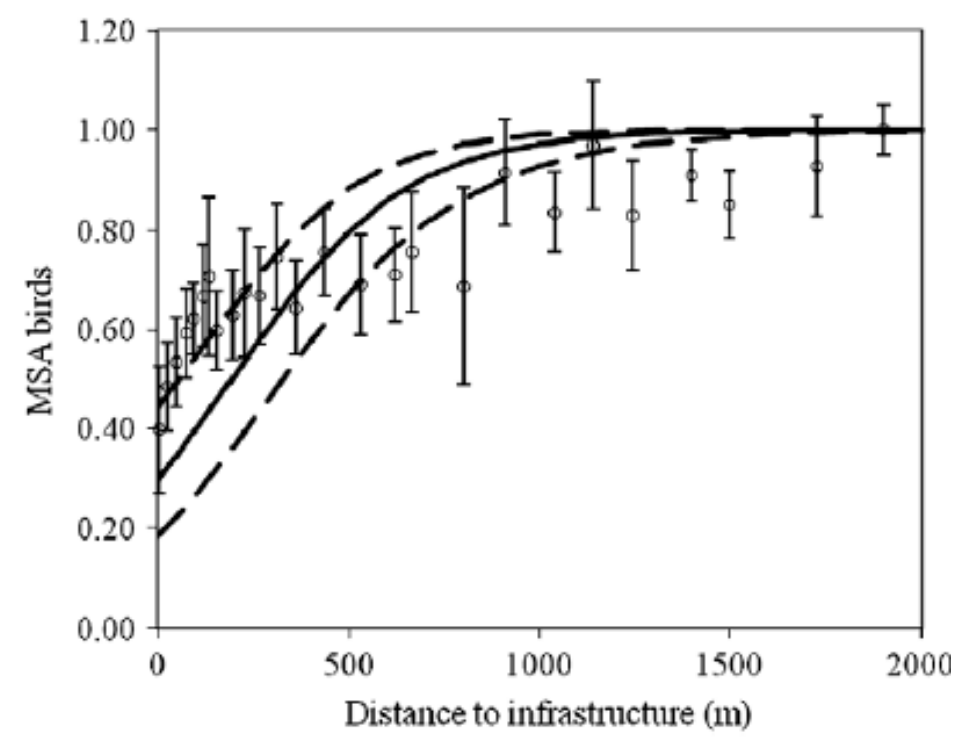

Figure 1. Mean species abundance (MSA) of birds as a function of distance to infrastructure (logistic regression). Open dots represent the pooled results of a meta-analysis per distance interval \pm SE. Solid black line denotes the estimated curve for the decline of MSA in proximity to infrastructure; dashed lines are the 95\% upper and lower limits of the confidence bands of the curve. Figure from Benítez-López et al. (2010). 


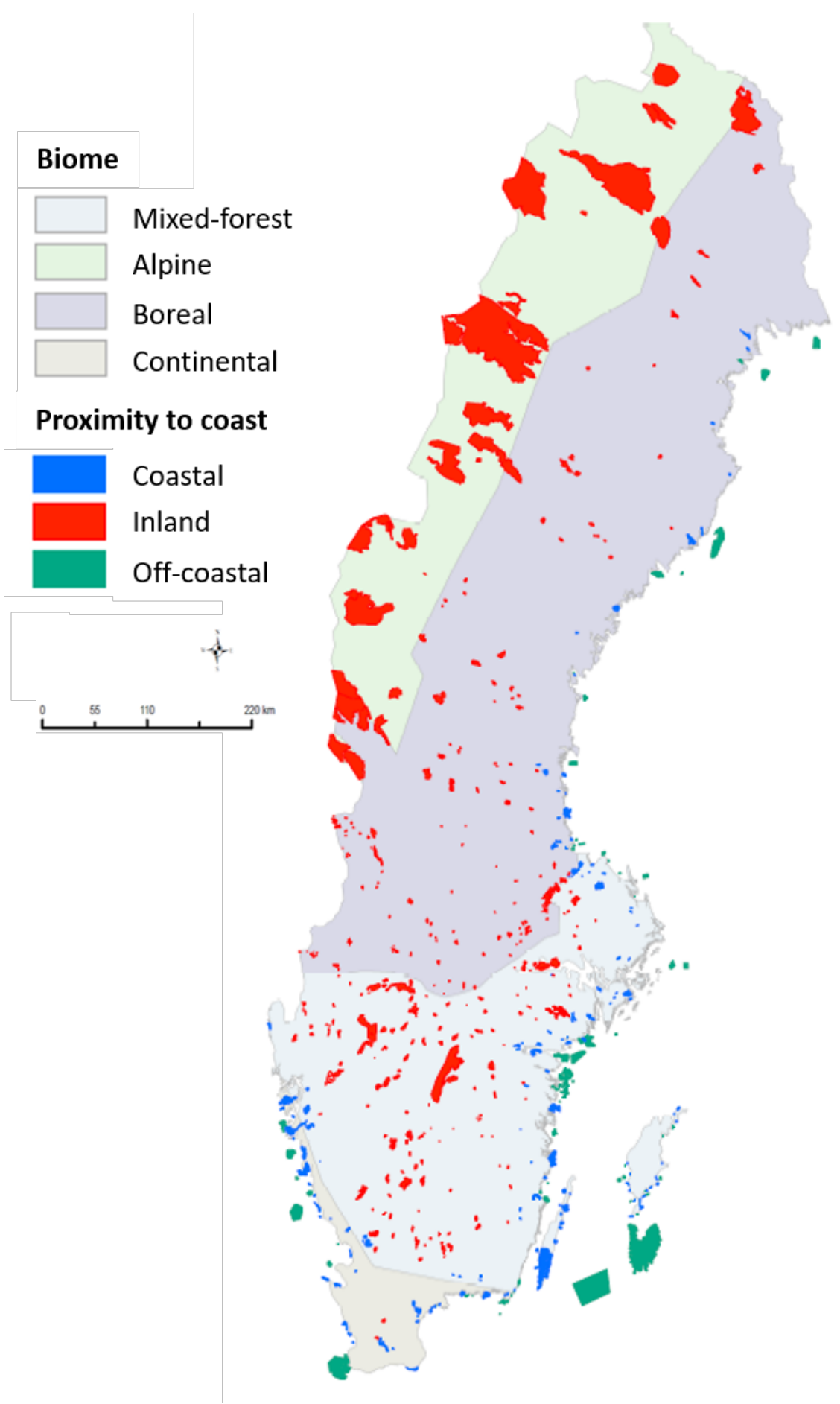

Figure 2. Special Protection Areas (SPAs) in Sweden divided by biogeographical region; see text for further explanation. 